Pace University

DigitalCommons@Pace

2012

\title{
United States v. Stevens: Win, Loss, or Draw for Animals?
}

David N. Cassuto

Elisabeth Haub School of Law at Pace University

Follow this and additional works at: https://digitalcommons.pace.edu/lawfaculty

Part of the Animal Law Commons, Constitutional Law Commons, and the First Amendment Commons

\section{Recommended Citation}

David N. Cassuto, United States v. Stevens: Win, Loss, or Draw for Animals?, 2 J. Animal Ethics 12 (2012), http://digitalcommons.pace.edu/lawfaculty/812/.

This Article is brought to you for free and open access by the School of Law at DigitalCommons@Pace. It has been accepted for inclusion in Pace Law Faculty Publications by an authorized administrator of DigitalCommons@Pace. For more information, please contact dheller2@law.pace.edu. 


\title{
ARTICLES
}

\section{United States v. Stevens: Win, Loss, or Draw for Animals?}

\author{
DAVID N. CASSUTO \\ David N. Cassuto, Pace Law School, Brazil-American \\ Institute for Law \& Environment.
}

\begin{abstract}
Robert Stevens was indicted for marketing dog-fighting videos in violation of 18 U.S.C. $\$ 48$, a law criminalizing depictions of animals being "intentionally mutilated, tortured, wounded, or killed..." The law aimed principally at "crush videos," but extended to dog-fighting as well. Stevens challenged the law's constitutionality and the Supreme Court eventually struck it down. This article explores whether the Stevens decision will have lasting implications for animal cruelty jurisprudence. It argues that the answer is "maybe, but probably not." In Stevens, the Court skirted the question of whether preventing animal cruelty can rise to the level of compelling state interest. Ironically, its avoidance of the issue may constitute a net positive for animal advocacy.
\end{abstract}

KEY WORDS: First Amendment, United States v. Stevens, animal cruelty, crush videos, constitutional law, compelling state interest, free speech

\section{INTRODUCTION}

"Crush videos" feature anonymous, leggy women wearing high heels, depicted from the waist down, grinding small animals to death underfoot while cooing dominatrix patter. They represented a growing niche market in the fetish video industry in the 1990s. The U.S. Congress reacted to this increasing demand by passing 18 U.S.C. $\$ 48$ in 1999. The bill criminalized visual or auditory depictions of animals being "intentionally mutilated, tortured, wounded, or killed" if such conduct violated federal or state law where "the creation, sale, or possession [of such materials] takes place." Images with "serious religious, political, scientific, educational, journalistic, historical, or artistic value" were exempt. The language of the bill was broad enough to include other types of expression unrelated to crush videos. This breadth concerned President William Clinton. Clinton declared when signing the bill that the executive branch would interpret the law to cover only depictions of "wanton cruelty to animals designed to appeal to a prurient interest in sex" (p. 2558).

Under President George W. Bush, the Department of Justice expanded the law's reach. Robert J. Stevens, proprietor of Dogs of Velvet and Steel Productions, was in- 
dicted for marketing dog-fighting videos in violation of $\$ 48$. Stevens challenged the law as unconstitutional, claiming it violated his First Amendment right of freedom of speech. ${ }^{1}$ Stevens was convicted at trial, but the U.S. Court of Appeals for the Third Circuit vacated his conviction (United States v. Stevens, 2008). The case eventually ended up before the Supreme Court, which upheld the Court of Appeals, although on slightly different grounds. The Supreme Court ruled the law unconstitutionally overbroad and all but invited Congress to pass a narrower law aimed specifically at crush videos (United States v. Stevens, 2010). Shortly thereafter, Congress enacted H.R. 5566, the Animal Crush Video Prohibition Act of 2010, and President Barack Obama signed the bill into law in December 2010. The new law aims explicitly at crush videos, which it defines as obscene (a type of expression that the Court has already determined lacks First Amendment protections). The narrow reach of the new law will likely enable it to avoid charges that it broadly and unconstitutionally curtails free expression.

The question before us here is not whether crush videos are prurient, distasteful, and sadistic (they are). Neither does the question involve the constitutionality of the law that the Court struck down (even apologists acknowledge that 18 U.S.C. $\$ 48$ was deeply flawed). This discussion is similarly unconcerned with whether the current law banning crush videos passes constitutional muster (there is little reason to think otherwise). Rather, the focus here is on what United States $v$. Stevens means for the world of animal protection and whether the Court's decision will have lasting implications for the campaign to rein in animal cruelty. In my view, the answer is maybe, but probably not. In Stevens, the Court for the second time skirted the question of whether preventing animal cruelty can rise to the level of compelling state interest. In doing so, it left an important and unsettled question of law for another day.

If preventing animal cruelty cannot rise to a compelling state interest, then when acts of cruelty interweave with fundamental rights, they cannot be outlawed. Broadly speaking, this conflict between animal cruelty and fundamental rights faced the Court in Stevens. Congress had passed 18 U.S.C. $\$ 48$, which aimed to prevent animal cruelty by outlawing its depiction. The Court determined that the ban interfered with the right of free expression and struck the law down. However, it left unresolved whether animal cruelty could be deemed so important that its prevention could potentially justify some constraints on free expression. If the Court were to so find, the ruling would have both cultural and legal significance. On a cultural level, the Court would be recognizing that preventing animal cruelty constitutes one the few allowable reasons for constraining speech. Congress could then use its power to ban cruelty (in its many forms) without fear of judicial contravention. Nonetheless, as noted previously, the Court chose not to rule on the compelling state interest question and struck down the law as unconstitutionally overbroad. Ironically, the Court's avoidance of the issue may constitute a net positive for animal advocacy. 


\section{FUNDAMENTAL RIGHTS VERSUS COMPELLING STATE INTERESTS}

The Third Circuit, in vacating Stevens's conviction and ruling 18 U.S.C. $\$ 48$ unconstitutional, stated (mistakenly, in my view) that the Supreme Court had previously suggested that preventing animal cruelty did not amount to a compelling state interest. ${ }^{2}$ That (mis)interpretation is important because the government had maintained that decreasing the acts of cruelty that go into the making of crush videos (whose provenance and creators are often very difficult to trace) required diminishing the market for the videos themselves. The most effective way to do that involved illegalizing the products. And, the argument went, since neither the expression nor the acts depicted contained any redeeming social value, Congress had the authority to ban them. However, outlawing a type of speech based on its content treads directly on the realm guarded by the First Amendment. Those protections can be overridden only if the restriction is necessary to further a compelling state interest. Thus, for Congress to ban the content of videos depicting illegal animal cruelty, its reasons for doing so must be both urgent and necessary.

\section{The First Amendment Versus Animal Cruelty_The Lukumi Case}

The Supreme Court has carved out several categories of speech to which it does not extend First Amendment protections. Each of them (obscenity, defamation, fraud, fighting words, and speech integral to criminal conduct) has a clear connection to a well-understood compelling state interest. The Stevens Court was properly reluctant to add a new class of speech to those existing categories. Yet, by declining to directly address the issue, the Court left the Third Circuit's analysis uncorrected. The Court had previously considered the question of whether prevention of animal cruelty rose to the level of compelling state interest in Church of Lukumi Babalu Aye v. City of Hialeah, a 1993 case dealing with animal sacrifice and the First Amendment. It did not, however, definitively rule on the issue in that case either (Cassuto, 2008).

In Lukumi, the Court faced a set of local ordinances banning animal sacrifice that were clearly aimed at a newly established Santería church in the city of Hialeah, Florida. The laws, enacted amid xenophobic rhetoric, outlawed animal sacrifice, a key component of Santería ritual. The church sued, claiming that the city was unconstitutionally interfering with its First Amendment right to freedom of religion. The Supreme Court held for the church, finding, amid some tortured reasoning, that the ordinances did indeed violate the First Amendment.

Like laws restricting speech, laws aimed at limiting religious practices must be necessary to serve a compelling state interest. The ordinances banning animal sacrifice in Lukumi purportedly aimed to deter animal cruelty. Consequently, if preventing animal cruelty constituted a compelling state interest, and the Hialeah laws were necessary to further that interest (and if they met several other conditions), then they theoretically could withstand constitutional scrutiny. However, though it discussed the compelling 
state interest question at some length, the Court invalidated the laws on other grounds, including overbreadth and under-inclusiveness. As a result, the compelling state interest question remained unresolved.

\section{Is Preventing Animal Cruelty a Compelling State Interest?}

The question of whether preventing animal cruelty constitutes a compelling state interest is not easily answered. The porous nature of existing state and federal statutes suggests that it might be difficult to classify protection of all animals as a state interest at all, much less a compelling one. Although companion animals enjoy some legal protections, their interests are always subordinate to the interests of the people who legally own them. Consequently, the animals' legal rights and ability to enforce those rights remain minimal. More dire still is the situation of non-companion animals. Many states exempt animal agriculture from the scope of their cruelty laws despite routine and ongoing brutality within the meat, dairy, and egg industries. Though many if not most Americans believe animals who are farmed ought to be better treated, only a small minority believes that those animals should not be killed for food. Most also do not oppose hunting or fishing, and an even smaller percentage opposes the use of animals for producing dairy and egg products.

On the federal side, the Animal Welfare Act excludes all farmed animals. It also excepts laboratory mice and rats, despite their comprising the overwhelming majority of vivisected animals. Similarly, the Humane Slaughter Act excludes chickens and turkeys. This means that more than $98 \%$ of the 10 billion animals annually killed for food in the United States lack even this basic legal protection.

Still, all 50 states have animal cruelty statutes, and the trend in recent years has been to widen rather than narrow the reach of those statutes. The range of protections and public attention afforded animals suggest that the nation's interest in animal protection varies and that existing laws do not always reflect the depth of public concern. The degree of interest depends on the particular animals and circumstances. Under the current legal framework, one can raise and then kill some animals (e.g., pigs, cows, and sheep) for food but not others (horses, dogs, and cats). Even among animals raised for slaughter, some must be killed "humanely," whereas others need not be.

\section{Is Preventing Certain Types of Animal Cruelty a Compelling State Interest?}

Clearly, the laws protect some animals more than others. It follows that even without any normative shift in society's view of animals, the state could possess a compelling interest in protecting certain animals from certain types of mistreatment. Other animals facing human-caused harm do not engender the same level of interest. Therefore, determining whether a compelling state interest exists would require a fact-specific inquiry focusing on existing laws, the animals involved, the degree of public concern, and other competing societal priorities (Cassuto, 2008).

An additional law outlawing a particular type of animal mistreatment while leaving others exposed to peril would blend readily into the patchwork that is the current animal protection regime. That law might, for example, protect certain animals from certain types 
of death that are viewed as not needful while allowing those same animals to be killed in other ways for other reasons. ${ }^{3}$ Wanton cruelty for purposes of entertainment or sexual gratification could fall into a state-defined category of non-needful uses. Consequently, a court might recognize that the state has a compelling interest in barring such behavior while nevertheless permitting other forms of animal killing and mistreatment. Existing categories of unprotected speech make clear that the Court's jurisprudence allows for such boundary-drawing.

\section{THE STEVENS MAJORITY USES TRADITION TO TRUMP PRECEDENT}

\section{Ferber Is on Point}

In 1982 in New York v. Ferber, the Court held child pornography to be unprotected speech. Its justification - that the market for child pornography was "intrinsically related" to the underlying abuse and therefore "an integral part of the production of such materials, an activity illegal throughout the Nation" (United States v. Stevens, 2010, p. 258) - seems directly pertinent to crush videos as well as to the animal-fighting videos for which Stevens was prosecuted. However, the Court refused to concede the analogy between the two laws or the circumstances that created them. Justice Robert's majority opinion goes to considerable lengths to distinguish Ferber.

For example, in explaining why depictions of cruelty are protected speech, the majority notes that there is no tradition in the United States of banning such depictions (as opposed to the behavior itself). It is hard to see the relevance of this reasoning. There is also no tradition in the United States of barring depictions of children being eviscerated. Nevertheless, there exists a strong tradition of banning the evisceration itself. I suspect that the Court would have little problem with a statute barring depictions of illegal eviscerations if it could be shown that the statute was a necessary step toward ending the practice.

Even Justice Alito's dissent in Stevens offers an affirmation that cruelty to animals cannot and should not be compared to human suffering. Despite acknowledging the many parallels between Ferber and Stevens and arguing that Ferber's holding should bind the Court and that "the state has a compelling interest in preventing the torture depicted in crush videos," Alito nonetheless avowed that "preventing the abuse of children is certainly much more important than preventing the torture of animals used in crush videos." Since the issue is not whether child exploitation is more or less important than animal brutalization but rather whether the latter has any redeeming social value, the comparison seems unhelpful.

The Court further rejected "ad hoc" balancing tests that weigh the relative social costs and benefits of the affected speech. This too seems off-topic. No one-including the government-argued that the curtailing speech was a matter to be taken lightly. Rather, the government maintained that the need to curtail the crush video market was 
so compelling as to make the law necessary. This reasoning resembles the approach in Ferber, wherein the Court held that the state's interest in eliminating the exploitation of children outweighed the state's interest in protecting speech of limited (or no) social value. It did not require a tradition of filmed child exploitation to reach its decision. The need to curtail the exploitation through restricting the video market was enough.

Stevens presented an analogous situation. The state sought to halt the spread of crush videos and other depictions of wanton animal cruelty by attacking the market for such images. That approach involved regulating speech. Therefore, the question before the Court could (or should) have been, does preventing animal cruelty rise to the level of compelling state interest? Rather than address the question directly, the Court struck down the law as overbroad (it found that the statute potentially illegalized too many types of legal behavior, including hunting videos and certain types of journalism) and rationalized its decision by manufacturing fanciful hypotheticals in which the law could be applied unconstitutionally. This practice, though a useful reasoning tool, is not dispositive. Law professors make their living dreaming up hypotheticals in which statutes might be applied in ways that violate the Constitution. The fact that such hypotheticals can be conjured does not typically suffice as justification for voiding a law. The issue is (or should be and traditionally has been) whether the law applies unconstitutionally to the party challenging that law. The Ferber Court made this clear (New York v. Ferber, 1982).

\section{Stevens Does Little to Change the Legal Landscape}

Even if the Stevens Court had recognized cruelty prevention as a compelling state interest, that still might not have salvaged 18 U.S.C. $\$ 48$. The law contained serious flaws, some of which had little to do with animal cruelty. For example, it exempted depictions that would otherwise be illegal but for their "serious" value. This "savings clause" supposedly restricted the law's reach solely to prurient depictions. However, it also put the purveyor of the expression in the position of having to prove the legality of her speech. That means the law presumed the speech to be unprotected. It fell to the speaker to disprove that assumption. That constitutionally problematic burden shift could have doomed the law all by itself.

In sum, the Stevens holding left the Court and the law with respect to animal cruelty in much the same limbo in which it had found them. A broad and flawed law was struck down; the Court's reluctance to make content-based restrictions on speech was reaffirmed; and the Court's disinclination to directly address the importance of preventing animal cruelty remains. Ironically, that unwillingness to tackle the cruelty question may actually amount to a net positive for animal advocates.

The complex and contradictory relationships Americans have with animals and animal cruelty, as well as the current makeup of the Court, make it unlikely that the compelling state interest argument would have received a sympathetic hearing. Meanwhile, the current state of limbo is not causing damage. Under the existing framework, states and the federal government can still enact animal protection laws. The Court's case law 
suggests that those protections can even place limits on protected expression as long as those constraints are incidental rather than integral to the intent of the law.

For example, in the 1990 case of Employment Division v. Smith, the Court held that if the state acts in a religiously neutral manner, it does not violate the Free Exercise Clause of the First Amendment even when its actions incidentally burden practitioners of a particular religious faith. In Smith, two drug counselors at an Oregon rehabilitation facility who were fired for ingesting peyote for sacramental purposes during a Native American ritual sued when they were denied unemployment compensation. The Court upheld the law and denied compensation because the state's intent was to prevent drug abuse, not to interfere with religious practices. Oregon did not intentionally target religious practices by enacting or enforcing the law. Any burdens placed on religion were incidental, and the law was rationally connected to a legitimate state interest. Since the law passed the "rational basis" test, it did not violate the First Amendment. Although Smith did not purport to overrule prior case law, previous cases had held that if a law burdened religious beliefs, it had to pass strict scrutiny (i.e., be narrowly tailored to meet a compelling state interest) to survive (Cassuto, 2008).

Applying the reasoning of Smith to the issue of animal cruelty, we can extrapolate that if a law designed to prevent animal cruelty were to incidentally burden a fundamental right (i.e., free speech), it need not pass the strict scrutiny test but rather need only be rationally connected to a legitimate state interest. That latter requirement is much easier to meet. Thus, even under the Court's existing jurisprudence wherein animal cruelty has not been recognized as a compelling state interest, cruelty statutes that incidentally burden fundamental rights can still survive.

\section{CONCLUSION}

All told, the Stevens ruling could have been a lot worse. Indeed, given the confused and conflicting laws and ethics regarding nonhuman animals in the United States, it is hard to see how it could have gone much better. What is more, the next time the issue comes before the Court, Congress will have already asserted its belief that preventing certain types of animal cruelty does rise to the level of compelling state interest. Section 2 of H.R. 5566, the new law banning crush videos, explicitly finds that "the Federal Government and the States have a compelling interest in preventing intentional acts of extreme animal cruelty." Although "extreme animal cruelty" may differ from simple animal cruelty (the law does not say), any difference would be of degree rather than of kind. Consequently, laws banning certain types of animal cruelty-even when such bans constrain fundamental rights - now have a better chance of surviving judicial review. Thus, since it galvanized Congress to write a new law explicitly recognizing that protecting animals amounts to a compelling state interest, the loss of the Stevens case may well have been the best possible result for animal protection. 


\section{Notes}

1. The First Amendment states in relevant part, "Congress shall make no law . . . abridging the freedom of speech, or of the press ... [ [or] to petition the Government for a redress of grievances."

2. See Stevens (2008, p. 226), listing reasons animal cruelty is not a compelling state interest and noting that "the Supreme Court has suggested that the kind of government interest at issue in $\$ 48$ is not compelling."

3. For example, a dog living in a domestic situation cannot be poisoned, mutilated, or sensorially deprived, yet if that same dog were to find himself or herself the subject of a sanctioned scientific research project, he or she could suffer any or all of those fates.

\section{References}

Cassuto, D. (2008). Animal sacrifice and the First Amendment: The case of Lukumi Babalu Aye. In T. Bryant, D. Cassuto, \& R. Huss (Eds.), Animal law and the courts: A reader (pp. 50-77). Eagan, MN: Thomson West.

Church of Lukumi Babalu Aye v. City of Hialeah, 508 U.S. 520 (1993).

Clinton, W. (1999, December 9). Presidential statement on signing H.R. 1887. Weekly Compilation of Presidential Documents, 35, 2557-2558.

Depiction of Animal Cruelty, Pub. L. No. 106-152, 18 U.S.C. $\$ 48$ (1999).

New York v. Ferber, $45^{8}$ U.S. 747 (1982).

United States v. Stevens, 533 F. 3rd 218 (2008).

United States v. Stevens, 130 S.Ct. 1577 (2010). 